\title{
Surgical site infection among gynecological group: risk factors and postoperative effect
}

\author{
Sunanda Bharatnur*, Vandana Agarwal
}

Department of Obstetrics and Gynecology, KMC Manipal (MAHE), Manipal, Karnataka, India

Received: 23 December 2017

Accepted: 24 January 2018

\section{*Correspondence:}

Dr. Sunanda Bharatnur,

E-mail: sunanda.somu77@gmail.com

Copyright: (C) the author(s), publisher and licensee Medip Academy. This is an open-access article distributed under the terms of the Creative Commons Attribution Non-Commercial License, which permits unrestricted non-commercial use, distribution, and reproduction in any medium, provided the original work is properly cited.

\begin{abstract}
Background: This study was carried out to evaluate the preoperative and intraoperative risk factors associated with surgical site infection amongst gynecology patients and its impact on postoperative recovery.

Methods: A prospective, observational study was conducted among 285 patients

Who underwent surgery over a period of two years. Diagnosis of SSI was made as per CDC criteria. Various risk factors and impact of SSI on postoperative recovery were analysed. Statistical analysis was carried out with SPSS version 16.0. Range and mean was calculated for continuous variables and overall incidence rate of SSI is also calculated. Pearson Chi-square test was used to test risk factor association with SSI. Odds ratios and 95\% confidence intervals (CI) was calculated. Significance was assumed at a p value of less than 0.05 .

Results: The incidence of SSI was found to be 52 out of 285 women (46\%). Majority of SSI, i.e. 49 out of 52 (94\%) were superficial in nature. Deep SSI was seen in 3 patients $(6 \%)$. No organ/space infection was noted in any patient. Women who were over 50 years had higher risk of developing SSI than women between 36 to 50 years (OR 0.519 Vs 0.214). The risk of SSI was 4 times in case of clean contaminated wounds as compared to clean wounds (OR 3.877). The risk further increased to 7 times in case of dirty wounds (OR 6.753). Other risk factors which are significantly associated with SSI were BMI ( $p$ value <0.001), midline incisions ( $p<0.001)$ and Mattress suture $(\mathrm{p}<0.001)$. Presence of previous scar had intraoperative adhesions, weaker scar and poor healing which predispose to development of SSI. Comorbidities which influence SSI's in the present study are diabetes mellitus (OR 5.49, 95\% CI 2.506-12.066, P <0.001), anaemia (OR 4.63, Cl 2.458-8.756) and hypertension (OR 2.46, Cl 0.994-6.117). Wound swab was sterile in $33(63 \%)$ cases and $18(35 \%)$ cases showed growth of the organism. Most common organism noted was E. coli $9(50 \%)$ followed by Klebsiella and Staph aureus.

Conclusions: SSIs are increasing in the current scenario due to increase in the number of surgeries, however they can be prevented by early identification and optimization of medical comorbidities and BMI. Meticulous preoperative workup and intraoperative surgical steps are important in reducing the risk of developing SSI. A decrease in infection rate can lead to substantial reduction in the burden of disease.
\end{abstract}

Keywords: Gynecological surgery, Postoperative impact, Risk factors, Surgical site infection

\section{INTRODUCTION}

In the current scenario many women are subjected to surgery for various reasons which includes gynaecological and obstetric causes. The effect of major surgeries has an impact on the post-operative recovery and life style. One of the major effects of surgery is on the incision and wound healing. The Centres for Disease Control and Prevention (CDC), defines Surgical site infection (SSI) as an infection occurring within thirty 
days of surgery, in one of the three locations: superficial, deep and or in organs or spaces opened or manipulated during an operation. ${ }^{1,2}$ Surgical site infection (SSI) is an important cause of healthcare associated infection. ${ }^{3}$

SSI development depends on peri operative factors, some of which can be modified like Diabetes mellitus, hypertension, BMI, smoking. Intra operative risk factors also have an influence on SSI like surgical scrub technique and duration. Pre-operative antibiotic prophylaxis skin preparation, duration of surgery, technique of surgery, minimizing blood loss during surgery. The post-operative risk factors like correction of anaemia, blood sugar control, minimizing hospital stay also has a positive impact on outcome of SSI.

Women undergoing pelvic surgery in reproductive age group, are susceptible to risk factors impacting postoperative recovery and by recognizing these risk factors help in reducing post post-operative complication. The aim of this study is to assess risk factors associated with SSI in women of reproductive age group undergoing surgical procedure and its effect on post-operative recovery.

\section{METHODS}

The study was done over a two year period (September 2015 to August 2017) with the study population comprising of 285 women (46\%) who underwent gynaecology surgeries. Subjects were sampled by random sampling. Postoperative follow up and incision site evaluation for SSI based on CDC guidelines was done for each patient.

\section{Inclusion criteria}

Women undergoing elective or emergency surgery in obstetrics and gynaecology were included in the study.

\section{Exclusion criteria}

Women who had undergone surgery in another hospital and referred to the hospital under study for further management were excluded.

\section{Statistical analysis}

Statistical analysis was carried out using SPSS version 16.0. Range and mean was calculated for continuous variables and overall incidence rate of SSI is also calculated. Pearson Chi-square test was used to test risk factor association with SSI. Odds ratios and 95\% confidence intervals (CI) was calculated. Significance was assumed at a $\mathrm{p}$ value of less than 0.05 .

\section{RESULTS}

Figure 1 above shows that, majority of SSI, i.e. 49 out of $52(94 \%)$ were superficial in nature. Deep SSI was seen in 3 patients $(6 \%)$. No organ/space infection was noted in any patient.

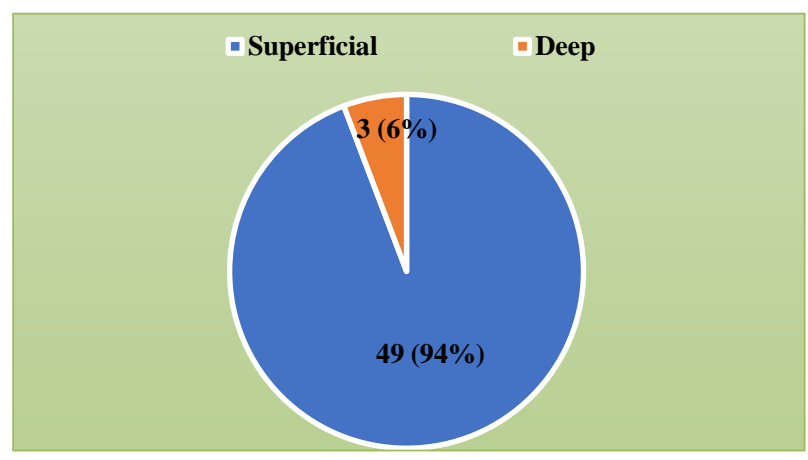

Figure 1: Type of surgical site infection $(\mathrm{N}=52)$.

As the age advances risk of SSI increases (Table 1). However, in this study it was seen that the women in the age group of 20 to 35 years had higher risk of acquiring SSI than between 36 to 50 years (OR 1.37 Vs 0.519). This could be probably due to the presence of more number of patients in the age group of 36 to 50 years as hysterectomy which was the most common gynaecology surgery performed was mainly done in the age group of 36 to 50 years.

Table 1: Association of age with SSI ( $=285)$.

\begin{tabular}{|c|c|c|c|c|c|}
\hline $\begin{array}{l}\text { Age } \\
\text { (years) }\end{array}$ & $\begin{array}{l}\text { SSI } \\
\text { present } \\
\text { n }(\%)\end{array}$ & $\begin{array}{l}\text { SSI } \\
\text { absent } \\
\text { n ( } \%)\end{array}$ & $\begin{array}{l}\text { Odds } \\
\text { ratio }\end{array}$ & $95 \% \mathrm{CI}$ & $\begin{array}{l}\text { p } \\
\text { value }\end{array}$ \\
\hline $\begin{array}{l}20-35 \\
(n=51)\end{array}$ & $\begin{array}{l}9 \\
(17.6)\end{array}$ & $\begin{array}{l}42 \\
(82.4)\end{array}$ & 1.373 & $\begin{array}{l}0.609- \\
3.093\end{array}$ & \multirow{3}{*}{0.05} \\
\hline $\begin{array}{l}36-50 \\
(n=154)\end{array}$ & $\begin{array}{l}35 \\
(22.7)\end{array}$ & $\begin{array}{l}119 \\
(77.3)\end{array}$ & 0.214 & $\begin{array}{l}0.106- \\
2.019\end{array}$ & \\
\hline $\begin{array}{l}>50 \\
(\mathrm{n}=80)\end{array}$ & $8(10)$ & $\begin{array}{l}72 \\
(90)\end{array}$ & 0.519 & $\begin{array}{l}0.186- \\
1.446\end{array}$ & \\
\hline
\end{tabular}

It was seen that women who were over 50 years had higher risk of developing SSI than women between 36 to 50 years (OR 0.519 Vs 0.214 ).

Table 2: Association of type of gynaecologic surgery with SSI.

\begin{tabular}{|c|c|c|c|}
\hline $\begin{array}{l}\text { Type of } \\
\text { gynecological } \\
\text { surgery }(\mathbf{N}=\mathbf{2 8 5})\end{array}$ & $\begin{array}{l}\text { SSI } \\
\text { present } \\
\text { n }(\%)\end{array}$ & $\begin{array}{l}\text { SSI } \\
\text { absent } \\
\text { n }(\%)\end{array}$ & $\begin{array}{l}\mathrm{p} \\
\text { value }\end{array}$ \\
\hline $\begin{array}{l}\text { Abdominal } \\
\text { hysterectomy }(n=142)\end{array}$ & $\begin{array}{l}30 \\
(21.1)\end{array}$ & $112(78.9)$ & \multirow{3}{*}{$<0.001$} \\
\hline $\begin{array}{l}\text { Exploratory } \\
\text { laparotomy }(n=53)\end{array}$ & $\begin{array}{l}21 \\
(39.6)\end{array}$ & $32(60.4)$ & \\
\hline $\begin{array}{l}\text { Others } \\
\text { (Laparoscopy/Vaginal } \\
\text { hysterectomy) }(\mathrm{n}=90)\end{array}$ & $1(1.1)$ & 89 (98.9) & \\
\hline
\end{tabular}

Table 2, depicts that the incidence of SSI was highest in case of women who underwent exploratory laparotomies than abdominal/vaginal hysterectomy and laparoscopic surgeries. The exploratory laparotomies were mainly 
done for ovarian tumors and adnexal pathologies. Exploratory laparotomy involves predominantly the use of midline skin incision, greater intraoperative blood loss and longer duration of surgery amongst other associated predisposing risk factors for development of SSI.

Table 3: Association of class of wound with SSI $(\mathrm{N}=285)$.

\begin{tabular}{|c|c|c|c|c|c|}
\hline Type of wound & SSI present, $\mathbf{n}(\%)$ & SSI absent, n (\%) & Odds ratio & $95 \% \mathrm{CI}$ & p value \\
\hline Clean $(n=24)$ & $0(0)$ & $24(100)$ & - & - & \multirow{3}{*}{0.003} \\
\hline Clean contaminated $(n=260)$ & $51(19.6)$ & $209(80.4)$ & 3.877 & 0.000 & \\
\hline Dirty $(n=1)$ & $1(100)$ & $0(0)$ & 6.753 & 0.000 & \\
\hline
\end{tabular}

Table 3 shows a strong correlation between wound class and development of SSI. The risk of SSI was about 4 times more in case of clean contaminated wounds as compared to clean wounds (OR 3.877). The risk further increased to about 7 times in case of dirty wounds (OR 6.753)

Table 4: Association of Body mass index with SSI $(\mathrm{N}=\mathbf{2 8 5})$.

\begin{tabular}{|c|c|c|c|}
\hline BMI & $\begin{array}{l}\text { SSI present } \\
\text { n }(\%)\end{array}$ & $\begin{array}{l}\text { SSI absent } \\
\text { n }(\%)\end{array}$ & $\begin{array}{l}\mathrm{p} \\
\text { value }\end{array}$ \\
\hline $\begin{array}{l}\text { Underweight } \\
(\mathrm{n}=17)\end{array}$ & 1 (5.9) & $16(94.1)$ & \multirow{5}{*}{$<0.001$} \\
\hline Normal $(n=152)$ & $15(9.9)$ & $137(90.1)$ & \\
\hline $\begin{array}{l}\text { Overweight } \\
(\mathrm{n}=87)\end{array}$ & $28(32.2)$ & $59(67.8)$ & \\
\hline Obese $(n=20)$ & $8(40)$ & $12(60)$ & \\
\hline $\begin{array}{l}\text { Morbidly obese } \\
(\mathrm{n}=9)\end{array}$ & $0(0)$ & $9(100)$ & \\
\hline
\end{tabular}

The gynaecological surgeries which come under clean category of wound are myomectomy, ovariectomy and cystectomies i.e. surgeries where vault is not opened. Hysterectomy which was the most common surgery is an example of clean-contaminated wound.

Exploratory laparotomy done in view of pyosalphinx /sepsis comes under the category of dirty wound. As the wound class increases from clean to dirty, risk of exposure to pathogenic microbes increases, thereby increasing the risk of development of surgical site infection.

As the BMI increases SSI also increases Table 4.

Table 5: Association of presence of previous surgeries with SSI $(\mathbf{N}=285)$.

\begin{tabular}{|c|c|c|c|c|c|}
\hline $\begin{array}{l}\text { H/o } \\
\text { previous } \\
\text { surgeries }\end{array}$ & $\begin{array}{l}\text { SSI } \\
\text { present } \\
\text { n }(\%)\end{array}$ & $\begin{array}{l}\text { SSI } \\
\text { absent } \\
\text { n }(\%)\end{array}$ & $\begin{array}{l}\text { Odds } \\
\text { ratio }\end{array}$ & $\begin{array}{l}95 \% \\
\text { CI }\end{array}$ & $\begin{array}{l}p \\
\text { value }\end{array}$ \\
\hline $\begin{array}{l}\text { Yes } \\
(n=129)\end{array}$ & $\begin{array}{l}28 \\
(21.7)\end{array}$ & $\begin{array}{l}101 \\
(78.3)\end{array}$ & 1.52 & $\begin{array}{l}0.834 \\
-2.788\end{array}$ & \\
\hline $\begin{array}{l}\text { No } \\
(n=156)\end{array}$ & $\begin{array}{l}24 \\
(15.4)\end{array}$ & $\begin{array}{l}132 \\
(84.6)\end{array}$ & & & 0.21 \\
\hline
\end{tabular}

Table 5 shows that the risk of acquiring SSI was 1.5 times higher in patients who had undergone a major surgery previously (OR 1.52, C.I:0.834-2.788). History of previous surgeries leads to presence of intraoperative adhesions, weaker scar and poor healing which predispose to development of SSI.

Table 6: Association of type of incision with SSI $(\mathrm{N}=\mathbf{2 8 5})$.

\begin{tabular}{|c|c|c|c|}
\hline $\begin{array}{l}\text { Type of incision } \\
\text { (Gynecology cases) }\end{array}$ & $\begin{array}{l}\text { SSI } \\
\text { Present } \\
\text { n }(\%)\end{array}$ & $\begin{array}{l}\text { SSI } \\
\text { Absent } \\
\text { n }(\%)\end{array}$ & $\begin{array}{l}\mathrm{p} \\
\text { value }\end{array}$ \\
\hline Pfannenstiel $(n=138)$ & $28(20.3)$ & $110(79.7)$ & \multirow[b]{3}{*}{$<0.001$} \\
\hline Midline $(n=56)$ & $21(37.5)$ & $35(62.5)$ & \\
\hline $\begin{array}{l}\text { Others } \\
\text { (laparoscopy/vaginal } \\
\text { hysterectomy) }(n=91)\end{array}$ & $3(3.3)$ & $88(96.7)$ & \\
\hline
\end{tabular}

As seen in Table 6, midline incisions were associated with higher risk for developing SSI than pfannenstiel and laparoscopic incision ( $\mathrm{p}$ value $<0.001$ ).

Table 7: Association of methods of skin closure with SSI $(N=285)$.

\begin{tabular}{|c|c|c|c|}
\hline $\begin{array}{l}\text { Method of skin } \\
\text { closure }\end{array}$ & $\begin{array}{l}\text { SSI } \\
\text { present } \\
\text { n }(\%)\end{array}$ & $\begin{array}{l}\text { SSI } \\
\text { absent } \\
\text { n }(\%)\end{array}$ & p value \\
\hline Mattress $(n=162)$ & $44(27.2)$ & $\begin{array}{l}118 \\
(72.8)\end{array}$ & \multirow{4}{*}{$<0.001$} \\
\hline Subcuticular $(n=79)$ & $5(6.3)$ & $74(93.7)$ & \\
\hline Staples $(n=11)$ & $2(18.2)$ & $9(81.8)$ & \\
\hline $\begin{array}{l}\text { Others (VH repair) } \\
(\mathrm{n}=33)\end{array}$ & $1(3)$ & $32(97)$ & \\
\hline
\end{tabular}

Table 7 depicts that the incidence of SSI was maximum with mattress suture $(27.2 \%)$ as compared to subcuticular stitch and staples ( $p$ value $<0.001$ ). Subcuticular stitch leads to better tissue approximation as compared to mattress stitch, thereby decreasing the risk of SSI.

Comorbidities which influence SSI's in the present study are diabetes mellitus (OR 5.49, 95\% CI 2.506-12.066, P $<0.001$ ), anaemia (OR 4.63, $\mathrm{Cl} 2.458-8.756)$ and hypertension (OR 2.46, Cl 0.994-6.117) (Table 8). 
Table 8: Association of co-morbidities with SSI $(\mathrm{N}=\mathbf{2 8 5})$.

\begin{tabular}{|c|c|c|c|c|c|c|}
\hline \multicolumn{2}{|c|}{ Comorbidities } & SSI Present n (\%) & SSI Absent n (\%) & Odds ratio & $95 \% \mathrm{CI}$ & p value \\
\hline \multirow{2}{*}{ Diabetes } & Yes & $15(48.4)$ & $16(51.6)$ & \multirow{2}{*}{5.49} & \multirow{2}{*}{$2.506-12.066$} & \multirow[t]{2}{*}{$<0.001$} \\
\hline & No & 37 (14.6) & $217(85.4)$ & & & \\
\hline \multirow{2}{*}{ HTN } & Yes & $8(33.3)$ & $16(66.7)$ & \multirow{2}{*}{2.46} & \multirow{2}{*}{$0.994-6.117$} & \multirow{2}{*}{0.04} \\
\hline & No & $44(16.9)$ & $217(83.1)$ & & & \\
\hline \multirow{2}{*}{ Anaemia } & Yes & $27(38)$ & $44(62)$ & \multirow{2}{*}{4.63} & \multirow{2}{*}{$2.458-8.756$} & \multirow[t]{2}{*}{$<0.001$} \\
\hline & No & 25 (11.7) & $189(88.3)$ & & & \\
\hline
\end{tabular}

Table 9: Organisms isolated on wound swab culture $(\mathrm{N}=18)$.

\begin{tabular}{|ll|}
\hline Organisms isolated on wound culture & n $(\%)$ \\
\hline E. coli & $9(50)$ \\
\hline E. coli + Klebsiella & $3(17)$ \\
\hline Staph aureus & $2(11)$ \\
\hline Pseudomonas & $2(11)$ \\
\hline Enterococcus faecium & $2(11)$ \\
\hline
\end{tabular}

Table 9 and Figure 2 show that majority of the wound swab culture were sterile. Growth was seen in 18 out of the 52 patients i.e. $35 \%$ of the patients with SSI. The most frequent organism cultured was E. coli $(50 \%)$, followed by Klebsiella and Staphylococcus aureus.

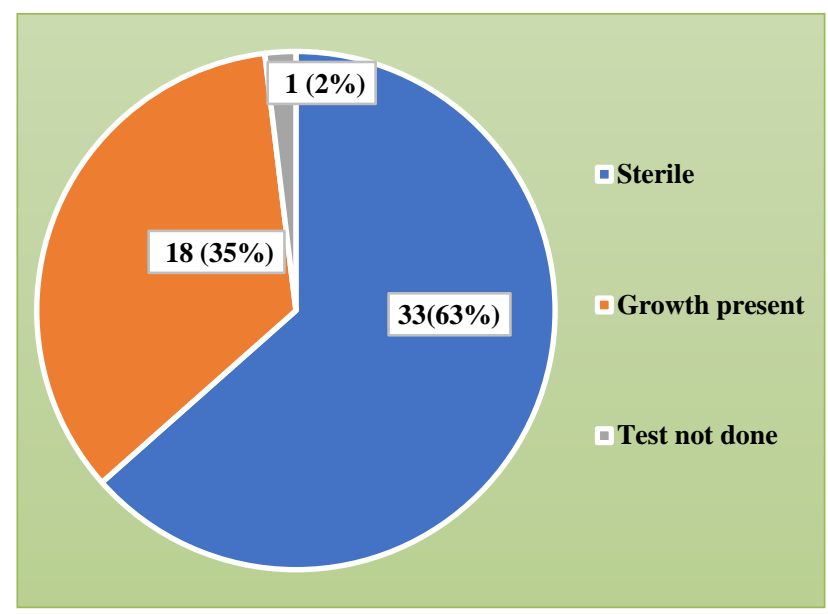

Figure 2: Wound swab culture report $(\mathrm{N}=52)$.

\section{DISCUSSION}

Assessment of surgical site infection is an important factor to determine the functioning of the health care system in the country. The incidence of SSI in low and middle-income countries is $11 \%$ and $2 \%$ high income countries. $^{1,2}$

In high-income countries, the SSI rates for gynaecological surgeries are similar to that of other surgical procedures. ${ }^{2}$ Hysterectomy for gynaecological causes is reported to have a SSI rate of $1.7 \% .^{3}$ A study conducted by Varsha et al reported an overall incidence of $6 \%$, while Vidyadhar B et al reported an incidence of $2.8 \%$ amongst gynaecology patients. ${ }^{4,5}$

Variation in incidence rate is attributable to the fact that SSIs are multifactorial and vary from hospital to hospital depending on the patient load, type of hospital (primary/secondary/tertiary) and the patient population (high risk / low risk).

In present study, a total of 285 patients were studied and the incidence was $18.2 \%$.

Higher incidence of SSI was noted in the present study, reason being multifactorial nature of SSIs. Moreover, this study was conducted in a tertiary care, teaching hospital which is a main referral centre for the management of high risk patients and oncology cases.

A study conducted by Shrestha et al where 648 women were studied, incidence of SSI was observed to be $12.6 \%$ which matches with our findings in the present study. ${ }^{6}$ According to a study conducted by Pathak A et al, 1173 patients were studied and the overall incidence of SSI was $7.84 \% .^{7}$ This finding is similar to the present study where slightly higher incidence was noted amongst gynaecology patients $(18.2 \%)$.

Similar finding was noted by Gregor $\mathrm{M}$ et al where the incidence of SSI doubled among gynaecologic patients compared to pregnant women $(1.31 \%$ vs $0.60 \%$ respectively). ${ }^{8}$

According to a cross-sectional analysis of the 2005-2009 American College of Surgeons National Surgical Quality Improvement Program participant use data files to analyse hysterectomies, different routes of hysterectomy were compared.

A total of 13,822 women were included, incidence of SSI after hysterectomy was $1.6 \%(n=221$ women). It is much lower than the present study SSI rate in gynaecology patients. The probable reason being presence of multiple comorbidities like anaemia and diabetes in addition to poor socioeconomic status evidenced in our study population.

Majority of SSIs become apparent within 30 days of an operative procedure and most often between the 5 th and 
10th postoperative days. They presents with erythema, discharge, and induration of the incision. ${ }^{9}$ In present study, the median postoperative day when SSI became apparent in gynaecology cases was postoperative day 7 .

SSI is multifactorial in nature, some of the risk factors are modifiable and some are not. The various risk factors have been analysed below:

\section{Age}

In this study, women between 36 to 50 years had 1.3 times higher risk of acquiring SSI than the ones who were in the age group of 10 to 35 years. (OR $1.353,95 \%$ CI $0.860-2.128)$. Likewise, those above 50 years had higher risk of SSI (OR $0.554,95 \%$ CI $0.253-1.209$ ). This is in concordance with what was found in a study done by Neumayer $L$ et al where it was observed that patients aged over 40 years had a statistically significant increased risk of developing SSI than those under 40 years (OR 1.24, 95\% CI 1.07 to 1.44). ${ }^{10}$ According to Pathak A et al, women older than 40 years were more likely to have SSI than those between 25 and 40 years of age (OR 2.95 vs. 2.19). ${ }^{7}$

\section{Diabetes}

Studies report a two to three fold increase in risk of developing an SSI in patients with diabetes. This is related to altered cellular immune function as a result of hyperglycaemia and advanced glycation end products which result in impaired healing.

In the present study, a strong correlation was noted between diabetes and risk of development of SSI ( $p$ $<0.001$ ). As age advances, glycaemic control worsens. Hence this difference in the age group could be one of the probable reasons as to why diabetic patients had a higher incidence of SSI.

\section{Body mass index (BMI)}

The effect of obesity on SSI has been investigated and studies report ORs between 2 and 7 for SSI in patients with BMI of $35 \mathrm{~kg} / \mathrm{m}^{2}$ or more. ${ }^{11}$ In the present study, BMI of more than 30 was identified as a very strong risk factor for SSI ( $\mathrm{p}<0.001)$.

According to Shah DK et al, women with BMIs 40 or higher had five times the odds of wound infection $(8.9 \%$ compared with $1.4 \%$, OR 5.34, CI 3.85-7.41). ${ }^{12}$ The magnitude of SSI was smaller after vaginal hysterectomy and no increased odds of wound complications were noted with a laparoscopic approach despite longer operative times.

According to Blikkendaal $\mathrm{MD}$ et al compared to abdominal hysterectomy, both laparoscopic and vaginal hysterectomy are associated with fewer postoperative complications and shorter length of hospital stay. ${ }^{13}$
Therefore, the feasibility of Laparoscopic and Vaginal Hysterectomy should be considered prior to the abdominal approach to hysterectomy in very obese and morbidly obese patients.

\section{Wound classification}

In a retrospective analysis of a large infection surveillance data set, the SSI incidence rate per 100 operations was $2.1,3.3,6.4$ and 7.1 for clean, cleancontaminated, contaminated and dirty wound classes, respectively. ${ }^{14}$

Another study reported that wound class was an independent predictor of SSI (ORs for cleancontaminated, contaminated and dirty wound classes were $1.04,1.7$ and 1.5 , respectively, $P<0.0001) .{ }^{10} \mathrm{~A}$ prospective study found that SSI was significantly increased in contaminated and dirty wounds (OR 2.3, $95 \%$ CI 2.0 to 2.7$).^{15}$

In the present study, similar observation was made. As the wound class increased, risk of SSI increased (overall $\mathrm{p}$ value 0.003 ). The ORs for clean-contaminated and dirty wound classes were 3.87 and 6.75 , respectively, i.e. clean-contaminated wounds had almost 4-fold higher risk of developing SSI and dirty wounds had about 7 times higher risk for developing SSI.

\section{Type of incision}

In the present study, risk of SSI was higher when midline skin incision was used than pfannenstiel or laparoscopy ports ( $P$ value 0.05). Similar finding was noted by Shrestha et al where incidence of SSI was noted to be more in women who had vertical skin incision $(\mathrm{p}=0.001)$ than horizontal incision. ${ }^{6}$

\section{Wound closure technique}

According to Shrestha et al, incidence of SSI was noted to be more in women when mattress suture was used as compared to subcuticular stitch (P value 0.001). ${ }^{6}$ In the present study, similar finding was noted. Risk of developing SSI was about 3.5 times higher, when mattress suture was used (OR 3.61, 95\% CI 1.952 6.700).

Tuuli et al reported a meta-analysis of 6 studies and showed an increased risk of wound infection with staples ( $n=803$ ) compared with suture skin closure $(n=684)$ (OR 2.06; 95\% CI 1.43, 2.98). ${ }^{16}$

A 2012 Cochrane Review of 18 trials by Mackeen et al showed no increased risk of wound infection with staple skin closure. ${ }^{17}$ Subsequently in 2014, a randomized controlled study of 746 women by the same group showed a lower risk of SSI with suture skin closure compared with staples (OR 0.43; 95\% CI 0.23, 0.78). ${ }^{18}$ 


\section{Nature of surgery (emergency vs elective)}

In present study, higher incidence of SSI was noted in emergency surgeries as compared to elective procedures (OR 1.26). According to a study by Karthika et al incidence of SSI was higher in emergency surgeries $(19.6 \%$ vs $3.06 \%)$ with significant $p$ value. ${ }^{19}$ It was concordant with higher SSI rate among the emergency case $16.01 \%$ followed by elective cases $3.67 \%$ reported by Amirta et al. ${ }^{20}$ Similar finding was reported according to a study by Shrestha et al. ${ }^{6}$ There is also increased risk of bacterial contamination, breaks in sterile technique and lack of timely antibiotic prophylaxis.

\section{Type of surgery}

According to Miroslav et al the incidence of SSI was $0.13 \%$ after laparoscopic surgery and $3.73 \%$ after major surgery. ${ }^{8}$ According to Lake AG, who conducted a crosssectional analysis of the 2005-2009 American College of Surgeons National Surgical Quality Improvement Program participant use data files to analyse hysterectomies. ${ }^{21}$ Different routes of hysterectomy were compared. A total of 13,822 women were included in the final analysis. The occurrence of SSI after hysterectomy was $1.6 \%(n=221$ women). The occurrence of deep and organ-space SSI was $1.1 \% \quad(n=54$ women $)$ after hysterectomy and one of the risk factors that was associated with SSI was the route of hysterectomy with an OR of 3.74 (95\% CI 2.26 to 6.22) for laparotomy compared to vaginal approach. ${ }^{22}$ Similar finding was noted in present study i.e. the risk of SSI was more in exploratory laparotomy and abdominal hysterectomy as compared to laparoscopic surgeries $(\mathrm{P}<0.001)$.

\section{Wound classification}

In the present study, it was observed that as the class of surgical wound increased, the incidence of SSI increased. The incidence of SSI was significantly higher in cleancontaminated and dirty wounds as compared to clean wound $(\mathrm{p}<0.05)$. According to Shrestha et al SSI rate was $0.0 \%$ for clean wounds, $2.9 \%, 15.3 \%$ and $18.7 \%$ for clean-contaminated, contaminated and dirty wounds respectively. ${ }^{10}$ Increased incidence of surgical site infections was associated with higher grades of wound.

Table 10: Comparison of BMI with SSI-present study versus other study.

\begin{tabular}{|lll|}
\hline Year & Study & Odds ratio \\
\hline 2009 & Olsen MA & 5.70 \\
\hline 2013 & Lake AG & 2.65 \\
\hline 2017 & Tetsuya et al & 2.40 \\
\hline 2017 & Present study & 3.84 \\
\hline
\end{tabular}

Table 10 shows that high BMI is significantly associated with development of SSI and the results found in this study were similar to other studies., ${ }^{3,21,23}$
Table 11: Comparison of Risk factors with SSIpresent study versus other study.

\begin{tabular}{|l|lll|}
\hline Risk factors & Year & Study & OR \\
\hline Comorbidities & & & \\
\hline & 2017 & Ashish et al & 5.76 \\
\hline Diabetes & 2017 & Present study & 3.84 \\
\hline & & & \\
\hline & 2007 & Neumyar & 3.00 \\
\hline & 2013 & Lake et al & 1.54 \\
\hline & 2017 & Ashish et al & 7.86 \\
\hline HTN & 2017 & Present study & 5.49 \\
\hline & & & \\
\hline & 2014 & Black et al & 2.90 \\
\hline & 2017 & Ashish et al & 3.07 \\
\hline Blood transfusion & 2017 & Present study & 2.46 \\
\hline & & \\
\hline & 2009 & Olsen MA & 2.40 \\
\hline & 2017 & Ashish et al & 3.78 \\
\hline & 2017 & Present study & 4.03 \\
\hline & & \\
\hline & 2014 & Tetsuya et al & 1.50 \\
\hline & 2017 & Ashish et al & 1.30 \\
\hline & 2017 & Present study \\
\hline & &
\end{tabular}

Table 11 shows that a strong association was noted between presence of medical comorbidities and previous surgeries with SSI. 2,3,7,10,18,21,23 Diabetic women were especially prone to develop SSI (OR 5.49). Likewise, hypertension and severe anemia requiring blood transfusion led to increased risk of developing SSI according to the present study and various other studies as seen above.

\section{Wound culture}

Wound culture was positive in 22 out of 106 patients i.e. $27 \%$, followed by Klebsiella and Staphylococcus aureus. Similar finding was observed in a study done by Shrestha et al where the most common pathogen isolated was $E$. coli (5 isolates, $29.4 \%){ }^{10}$

According to a study done by Karthika et al, out of 62 cases the predominant isolate was Staphylococcus aureus (35 isolates, 56.45\%) followed by Pseudomonas aeruginosa, Proteus vulgaris, E. coli, Klebsiella and Enterococcus. ${ }^{19}$

\section{CONCLUSION}

Surgical site infections can be minimized by early identification and optimization of medical comorbidities like diabetes, anaemia and hypertension and foster BMI. Surgical site infections cannot be completely eradicated; however, it can be curtailed by proper evaluation of the patient so that the burden of the disease, both for patients and the healthcare service providers can be reduced in terms of the morbidity and mortality. It can also bring down the hospitalization days and its cost. 
Funding: No funding sources

Conflict of interest: None declared

Ethical approval: The study was approved by the Institutional Ethics Committee

\section{REFERENCES}

1. World Health Organization 2016: Global guidelines on the prevention of surgical site infection. Available at http://www.who.int/gpsc/global-guidelinesweb.pdf

2. Black JD, de Haydu C, Fan L, Sheth SS. Surgical site infections in gynecology. Obstet Gynecol Surv. 2014; 69(8):501-10.

3. Olsen MA, Higham-Kessler J, Yokoe DS, Butler AM, Vostok J, Stevenson KB et al. Prevention epicenter program CfDC, prevention: developing a risk stratification model for surgical site infection after abdominal hysterectomy. Infect Control Hosp Epidemiol. 2009;30(11):1077-83.

4. Shahane V, Bhawal S, Lele MU. Surgical site infections: A one year prospective study in a tertiary care center. Int J Health Sci. 2012 Jan;6(1):79-84.

5. Bangal VB, Borawake SK, Shinde KK, Gavhane SP. Study of Surgical Site Infections following Gynaecological Surgery at tertiary care teaching hospital in Rural India. Int J Biomed Res. 2014 Feb;5(2):113-6.

6. Shrestha S, Shrestha R, Shrestha B, Dongol A. Incidence and Risk Factors of Surgical Site Infection Following Cesarean Section at Dhulikhel Hospital. Kathmandu Univ Med J. 2014;46(2):113-6.

7. Pathak A, Mahadik K, Swami MB, Roy PK, Sharma M, Mahadik VK et al. Incidence and risk factors for surgical site infections in obstetric and gynecological surgeries from a teaching hospital in rural India. Antimicrob Resist Infect Control. 2017;6:66.

8. Gregor M, Paterová P, Buchta V, Ketřánek J, Špaček J. Healthcare-associated infections in gynecology and obstetrics at a university hospital in the Czech Republic. Int J Gynecol Obstet. 2014 Sep;126(3):240-3.

9. Pal N, Guhathakurta R, Al-Jumaily EF, Al-Mudallal NH, Muhimen NA, Al-Shaibany AA. Surgical site infection in surgery ward at a tertiary care hospital: the infection rate and the bacteriological profile. J Pharm. 2012 Sep;2(5):1-5.

10. Neumayer L, Hosokawa P, Itani K, El-Tamer M, Henderson WG, Khuri SF. Multivariable predictors of postoperative surgical site infection after general and vascular surgery: results from the patient safety in surgery study. J Am Coll Surg. 2007;204(6):117887

11. Black JD, de Haydu C, Fan L, Sheth SS. Surgical site infections in gynecology. Obstet Gynecol Surv. 2014;69(8):501-10.

12. Shah DK, Vitonis AF, Missmer SA. Association of body mass index and morbidity after abdominal, vaginal and laparoscopic hysterectomy. Obstet Gynecol. 2015;125(3):589-98.
13. Blikkendaal MD, Schepers EM, van Zwet EW, Twijnstra AR, Jansen FW. Hysterectomy in very obese and morbidly obese patients: a systematic review with cumulative analysis of comparative studies. Arch Gynecol Obstet. 2015;292(4):723-38.

14. Culver DH, Horan TC, Gaynes RP, Martone WJ, Jarvis WR, Emori TG et al. Surgical wound infection rates by wound class, operative procedure, and patient risk index. National Nosocomial Infections Surveillance System. Am J Med. 1991;91(3):152.

15. Kaye KS, Schmit K, Pieper C, Sloane R, Caughlan $\mathrm{KF}$, Sexton DJ, et al. The effect of increasing age on the risk of surgical site infection. J Infect Dis. 2005;191(10):56-62.

16. Tuuli MG, Rampersad RM, Carbone JF, Stamilio D, Macones GA, et al. Staples compared with subcuticular suture for skin closure after cesarean delivery: a systematic review and meta-analysis. Obstet Gynecol. 2011;117(3):682-90.

17. Mackeen AD, Berghella V, Larsen ML. Techniques and materials for skin closure in caesarean section. Cochrane Database Syst Rev. 2012;11.

18. Mackeen AD, Khalifeh A, Fleisher J, Vogell A, Han C, Sendecki J et al. Suture compared with staple skin closure after cesarean delivery: a randomized controlled trial. Obstet Gynecol. 2014;123(6):116975

19. Priya KS, Somasundar VM, Rajesh JG, Priya P, Muthulakshmi, Raj KM et al. Surgical site infection and incidence of mrsa using phenotypic and genotypic methods from tertiary care hospital. IOSRJDMS. 2016;15(7):111-5.

20. Bhadauria AR, Hariharan C. Clinical study of post operative wound infections in obstetrics and gynaecological surgeries in a tertiary care set up. Int J Reprod Contracept Obstet Gynecol. 2016 Dec 13;2(4):631-8.

21. Lake AG, McPencow AM, Dick-Biascoechea MA, Martin DK, Erekson EA. Surgical site infection after hysterectomy. Am J Obstet Gynecol. 2013 Nov;209(5):490-e1.

22. Ahmadzia HK, Patel EM, Joshi D, Liao C, Witter F, Heine RP et al. Obstetric surgical site infections: 2 grams compared with 3 grams of Cefazolin in morbidly obese women. Obstet Gynecol. 2015;126(4):708-15.

23. Kawakita T, Landy HJ. Surgical site infections after cesarean delivery: epidemiology, prevention and treatment. Maternal Health Neonatol Perinatol. 2017 $\operatorname{Dec} ; 3(1): 12$.

Cite this article as: Bharatnur S, Agarwal V. Surgical site infection among gynecological group: risk factors and postoperative effect. Int J Reprod Contracept Obstet Gynecol 2018;7:966-72. 